\title{
Less is More, or Not? On the Interplay between Bundles of Slack Resources, Firm Performance and Firm Survival
}

\author{
INE PAELEMAN \\ Ghent University \\ Department of Accounting, Corporate Finance and Taxation \\ Sint-Pietersplein 7 \\ 9000 Gent \\ BELGIUM \\ E-mail: Ine.Paeleman@UGent.be \\ TOM VANACKER \\ Ghent University \& Vlerick Business School \\ Department of Accounting, Corporate Finance and Taxation \\ Sint-Pietersplein 7 \\ 9000 Gent \\ BELGIUM \\ E-mail: TomR.Vanacker@UGent.be
}

Paeleman, I., \& Vanacker, T. (2015). Less is more, or not? On the interplay between bundles of slack resources, firm performance and firm survival. Journal of Management Studies, 52(6), $819-848$

ACKNOWLEDGMENTS We thank three $J M S$ reviewers, Dries Faems (the editor), a second $J M S$ editor, Gaetan de Rassenfosse, Maw-Der Foo, Sophie Manigart, Mirjam Knockaert and Shaker Zahra, for helpful comments on prior drafts of this paper. This paper further benefited from presentations at the VICO conference on the financing of entrepreneurial ventures in Europe (Stresa, Italy), the 2012 Babson College Entrepreneurship Research Conference (Fort Worth, USA) and the 2012 Academy of Management Meeting (Boston, USA). We acknowledge the data collection support of all VICO partners and financial support from The Hercules Foundation (AUGE/11/13) and The Research Foundation - Flanders. 


\title{
Less is More, or Not? On the Interplay between Bundles of Slack Resources,
}

\section{Firm Performance and Firm Survival}

\begin{abstract}
Although a significant body of research has investigated the independent effects of distinct types of slack resources, current theoretical and empirical work does not sufficiently clarify how bundles of slack resources affect firm outcomes. Drawing on the resource constraints literature and the slack literature, we investigate how distinct bundles of financial and human resource (HR) slack influence firm performance and survival. Using a sample of 4,715 European information and communication technology (ICT) firms, we show that neither parallel resource abundance (having slack in financial and human resources) nor parallel resource constraints (lacking slack in financial and human resources) are optimal for firm performance and survival. However, firms with selective constraints that combine slack in financial resources with constraints in human resources exhibit superior performance without decreased survival prospects. Taken together, this study extends current research by providing a more nuanced view of the relationships between slack resources, firm performance and firm survival.
\end{abstract}

Keywords: entrepreneurship, performance, resource bundles, resource constraints, slack resources, survival

\section{INTRODUCTION}

How do slack resources - those resources that firms possess in excess of resource demands from current business-affect firm performance? Scholars have long studied this question, but mixed findings have emerged (for reviews, see Daniel et al., 2004; Tan and Peng, 2003). In the classic resource-based view (RBV), having more resources is often considered better than having fewer 
resources (Barney, 1991; Cooper et al., 1994). Organization theorists further argue that slack buffers firms from environmental jolts and fosters strategic behavior, thereby enhancing performance (Bromiley, 1991; Cyert and March, 1963; Greenley and Oktemgil, 1998; Singh, 1986; Thompson, 1967). However, others argue that there are costs associated with large resource endowments, such as core rigidities and reduced experimentation (Mosakowski, 2002). Resource constraints theorists assert that firms with fewer resources leverage their resources more efficiently and, as a result, can survive and even flourish despite experiencing resource constraints (Baker and Nelson, 2005; Starr and MacMillan, 1990).

Researchers have sought to reconcile these conflicting perspectives on the performance effects of slack in at least two ways. First, scholars have argued that the performance effect of one type of slack depends on the level of that type of slack. Specifically, increasing slack levels have a positive effect on performance, but this effect gradually diminishes with increasing slack levels and eventually becomes negative at high levels, resulting in an inverted U-shaped relationship between slack and performance (Bourgeois, 1981; George, 2005; Mousa and Reed, 2013; Nohria and Gulati, 1996; Sharfman et al., 1988; Tan and Peng, 2003). Second, scholars have focused on contingent factors that moderate the slack-performance relationship. Specifically, studies have shown how industry conditions (Bradley et al., 2011a; George, 2005; Lecuona and Reitzig, 2014; Verbeke and Yuan, 2013) and firm characteristics (George, 2005; Mishina et al., 2004; Vanacker et al., 2013) impact the performance effects of slack.

We take a different approach and ask the following research questions: (a) how do distinct bundles of financial (i.e., excess cash) and HR slack (i.e., excess employees on the payroll) influence firm performance and survival, and (b) are different bundles optimal for new firms (defined here as firms that have been in existence for eight years or less) and later-stage firms? Theoretically, our approach is consistent with the view of resource-based theorists (Barney, 1991; 
Mosakowski, 2002; Wernerfelt, 1984), who argue that firm performance is dependent on the characteristics of a firm's bundle of resources rather than its individual resources. Because enhancing (i.e., one resource magnifies the impact of another resource) and suppressing (i.e., one resource diminishes the impact of another resource) relationships may exist between resources (Black and Boal, 1994), slack in one type of resource may benefit or harm performance, depending on the level of other types of resource slack. Hence, there is a need to consider the performance effects of distinct bundles of slack resources.

Empirical evidence on the extent to which bundles of slack resources affect firm outcomes is scarce because prior research has focused on the independent effects of one (Bradley et al., 2011a,b; George, 2005; Greve, 2003; Lecuona and Reitzig, 2014; Love and Nohria, 2005; Mellahi and Wilkinson, 2010; Natividad, 2013) or multiple types of slack (Mishina et al., 2004; Mousa and Reed, 2013; Vanacker et al., 2013; Verbeke and Yuan, 2013; Voss et al., 2008). Some recent exploratory studies have focused on the impact of resource bundles on firm performance. Gruber et al. (2010), for instance, study how bundles of resources and capabilities are configured in the sales and distribution function and determine how these bundles are related to performance, whereas Mousa et al. (2013) show that initial public offerings (IPOs) with low slack configurations exhibit higher performance than do IPOs with high slack configurations. However, these studies have not theorized exactly which bundles of financial and HR slack contribute most to firm performance and survival. Moreover, although scholars have suggested that the value of resource bundles changes as firms develop (Sirmon et al., 2011), these cross-sectional studies do not address how distinct bundles of slack resources affect firm performance as firms age.

In this paper, we develop a conceptual framework for the relationship between distinct bundles of slack resources, firm performance and firm survival and for the temporal nature of these relationships. To test our model, we use a sample of 4,715 European ICT firms. By our 
focusing on one industry, the unobserved heterogeneity among firms resulting from variance in industry conditions is reduced. In addition, the ICT industry is a typical example of a highvelocity environment with constantly changing demand, competition and technology (Wirtz et al., 2007). In such an environment, slack resources are thought to be especially important because they provide the necessary means for discovering and exploiting new strategic options, which is essential for maintaining alignment with the rapidly changing environment (Greenley and Oktemgil, 1998).

In addition to contributing to the slack literature, this study also contributes to a broader resource-based literature. Our study creates a bridge between classic resource-based theory (i.e., "more is better" perspective) and the resource constraints literature (i.e., "less is more" perspective). We show how a combination of the two perspectives where firms combine slack in unabsorbed (financial) resources with constraints in absorbed (human) resources leads to superior performance without hampering firm survival. By studying bundles of slack resources and showing how particular bundles lead to performance advantages while others lead to performance disadvantages, we also provide essential extensions that cross-validate the theoretical value of resource-based theories (e.g., Armstrong and Shimizu, 2007; Priem and Butler, 2001).

\section{THEORY}

\section{Bundles of Slack Resources}

Resource-based theories depict firms as heterogeneous bundles of resources (Barney, 1991; Mosakowski, 2002; Wernerfelt, 1984) and stress the importance of slack resources (or lack thereof) rather than the absolute amount of resources possessed by firms (Mishina et al., 2004; Penrose, 1959). In the classic RBV, particular attention has been devoted to the characteristics of resources that lead to competitive advantage (Barney, 1991). It is argued that firms with "more 
valuable resources than other firms" will exhibit superior performance (Peteraf and Barney, 2003, p. 317, emphasis added). Resource constraints theorists, however, argue that value can be destroyed by adding more resources to a firm's resource pool (Mosakowski, 2002). Especially in an entrepreneurial setting, resource constraints drive entrepreneurs to work more efficiently and foster entrepreneurial ingenuity, which ultimately benefits a firm's performance and survival prospects (Baker and Nelson, 2005).

Resource slack and resource constraints are generally depicted as two extremes on a continuum of possible resource positions (Dolmans et al., 2014; George, 2005). At one end of this continuum, firms accumulate slack when the resources available exceed those needed for the basic operations of the firm; at the other end of the continuum, constraints arise when fewer resources are available than needed. Empirically, prior research largely views this continuum as one-dimensional in nature (i.e., firms either have slack resources or are resource constrained) based on the specific type of resource being studied, typically financial resources (see, for instance, George, 2005). However, when firms are conceived as bundles of resources, they may for instance combine constraints in one type of resource with slack in other types of resources. Hence, the classic RBV and resource constraints literatures are not necessarily incongruent, but the question becomes which combinations of resource slack and resource constraints are better for firm performance and survival.

We focus on bundles of slack or constraints in two resources, namely, financial and human resources. Empirically, these resources are the most frequently examined and are found to be the most clearly related to firm emergence and development (Cooper et al., 1994; Gilbert et al., 2006). Theoretically, moreover, financial and HR slack lie at opposing ends of a continuum, representing the extent to which slack resources are redeployable elsewhere (Singh, 1986; Tan and Peng, 2003). Financial (available) slack represents unabsorbed slack, which consists of 
resources that are currently uncommitted and are readily available for redeployment within a firm, such as excess cash (Voss et al., 2008). HR slack represents absorbed slack, which consists of resources that are highly idiosyncratic to context and more difficult to redeploy, such as an excess of employees on the payroll (Mishina et al., 2004).

Figure 1 summarizes the four distinct bundles of slack resources that exist when considering both financial and HR slack. First, some firms may experience parallel resource abundance, i.e., having both financial and HR slack (quadrant I). Other firms may experience parallel resource constraints, i.e., lacking both financial and HR slack (quadrant IV). Third, firms may also be characterized by a pattern of selective resource constraints, which means that they are constrained in one resource but have slack in another. Two distinct types of selective resource constraints exist in our study: selective resource constraints in human resources (quadrant II), which implies that firms combine slack in financial resources with constraints in human resources and selective resource constraints in financial resources (quadrant III), which implies that firms combine HR slack with constraints in financial resources.

\section{INSERT FIGURE 1 ABOUT HERE}

Entrepreneurial firms, such as those we study, are likely to be found in any of the four quadrants identified in Figure 1. This is true for at least two reasons. First, prior research shows how entrepreneurial firms differ significantly in their early resource endowments (Heirman and Clarysse, 2007; Shane and Stuart, 2002). Some entrepreneurial firms may have accumulated slack from their early operations and initial stock of capital (Fichman and Levinthal, 1991), whereas others are more constrained. Second, extant research suggests that firms with slack in one type of resource do not necessarily have slack in other types of resources; in other words, empirically, correlations between different types of slack are generally low (Mishina et al., 2004; 
Voss et al., 2008). Below, we develop our hypotheses, which relate to how these distinct bundles of slack resources affect firm performance and survival.

\section{Slack Bundles and Firm Performance}

Although firms with parallel resource abundance (Figure 1: quadrant I) have all the resources necessary to discover and exploit new opportunities, resources do not discover and exploit opportunities by themselves (Sirmon et al., 2011). Rather, entrepreneurs should utilize these resources to perceive and act upon new opportunities (Penrose, 1959). Resource constraints theorists posit that there are important costs associated with large resource endowments, such as core rigidities and reduced experimentation, which impair an entrepreneur's ability to perceive and act upon opportunities (Mosakowski, 2002).

When firms have abundant slack resources and do not experience constraints, entrepreneurs are likely to feel comfortable with the status quo and are less likely to take strategic actions (e.g., Mosakowski, 2002). Debruyne et al. (2010), for instance, show that abundant resources lead people to believe that they are able to react effectively to competitive attacks but at the same time make them less motivated to take actions to counter such attacks. Entrepreneurs in firms with parallel resource abundance are also more likely to hold the attitude that their firms are doing well relative to entrepreneurs in firms that are experiencing constraints (Danneels, 2008). This attitude leads to more complacent, inward-looking and risk-averse behavior in the firms with parallel resource abundance (Stevenson and Gumpert, 1985), which hampers strategic change and firm performance (Kraatz and Zajac, 2001).

Moreover, people have a natural tendency to engage in exploitation at the expense of exploration (Levinthal and March, 1993). Firms characterized by parallel resource abundance are expected to focus their attention more on exploiting and leveraging their existing resource 
bundles to generate profits (Agarwal and Audretsch, 2001; Kraatz and Zajac, 2001). Bhide (1992), for instance, argues that entrepreneurial start-ups that acquire significant amounts of external resources are confronted with a serious challenge because external stakeholders often push firms to exploit their existing strategies - for which they raised those resources - but this "can hinder entrepreneurs from following the try-it, fix-it approach required in the uncertain environments in which start-ups flourish" (p. 112). More generally, firms with parallel resource abundance are more likely to focus on "static efficiency" by applying and improving their current resource bundles at the expense of their "dynamic efficiency" from pursuing new strategic options, which is required in high-velocity environments to maintain performance advantages (Ghemawat and Costa, 1993; Kraatz and Zajac, 2001). Firms that experience resource constraints (Figure 1: quadrants II, III and IV), however, are forced to seek alternative ways to create profits and, as a result, will engage more often in exploration to pursue new and more radical business opportunities (Mosakowski, 2002).

The resource constraints literature further posits that firms with fewer resources rather than more are likely to leverage their existing resources more efficiently (Baker and Nelson, 2005). Hamel and Prahalad (1993) provide a range of resource leveraging examples, such as Dell Computer, which in its early years "could never have matched Compaq's dealer network or IBM's direct sales force, so the company chose to sell its computers by mail” (p. 83). Starr and MacMillan (1990) further show how resource-constrained entrepreneurs rely on resource cooptation strategies (such as obtaining access to resources that are underutilized by others through borrowing, begging or scavenging) that can greatly benefit firm performance. Finally, the mechanism of "bounded creativity" argues that the human mind is more productive when some restrictions apply (i.e., when entrepreneurs experience resource constraints), which results in 
identifying not only more but also more creative and diverse opportunities (Goldenberg et al., 2001).

In sum, the resource constraints literature suggests that resource abundance is not necessarily beneficial (Garud and Karnoe, 2003; Mosakowski, 2002) and that, especially in an entrepreneurial setting, firms may benefit from experiencing resource constraints (Baker and Nelson, 2005). This benefit occurs for both firms experiencing parallel constraints (Figure 1: quadrant IV) and those experiencing selective constraints (Figure 1: quadrants II and III). Baker and Nelson (2005), for example, provide detailed case study evidence showing how entrepreneurs have an impressive ability to create something from nothing in one specific domain or even in multiple domains, thereby pursuing new opportunities despite their inability (or refusal) to attract the multiplicity of resources that other firms consider to be essential. Thus,

Hypothesis 1: Firm performance will be higher when firms experience resource constraints (i.e., quadrants II, III and IV) relative to parallel resource abundance (i.e., quadrant I).

Not all bundles with resource constraints are the same, however, and we argue that distinct bundles with resource constraints have their own performance effects. Specifically, in contrast to firms that experience selective resource constraints (Figure 1: quadrants II and III), firms that experience parallel constraints (Figure 1: quadrant IV) may be more challenged and in danger of finding themselves in a resource constraints trap. There are limits with regard to how far resources can be stretched, and multiple constraints may become insurmountable (Hoegl et al., 2008). Moreover, entrepreneurs may become so focused on finding ways to make do with their limited resources that they lack time to focus on other critical tasks, such as managing their firms and identifying new opportunities (Patzelt and Shepherd, 2009). Therefore, combining 
constraints in one resource with slack in another resource, rather than experiencing constraints in multiple resources, is expected to lead to higher performance because selective constraints allow entrepreneurs to avoid the resource constraints trap.

Moreover, we expect that firms that combine slack in financial resources with constraints in human resources (Figure 1: quadrant II) will outperform firms that combine HR slack with constraints in financial resources (Figure 1: quadrant III). Absorbed HR slack is "sticky" and difficult to relocate in the short term, which limits firms' strategic flexibility (Mishina et al., 2004; Voss et al., 2008). Specifically, existing human resources—and their related specialized skills-will fit with the existing strategies being pursued (Mishina et al., 2004). When the competitive environment changes and new skills and strategies are required, existing human resources may become obsolete and even ill-suited to address these changes in the environment. For example, one of the significant challenges for firms that are attempting to make the transition into the Internet of Things (IoT) business is that current employees, irrespective of their functional backgrounds, lack the skills and capabilities that meet the needs of IoT business models (Fitts, 2014). The existing buffer of human resources may then push firms towards exploiting existing resource bundles and strategies at the expense of exploration and reacting to changes in the environment (Voss et al., 2008). Such behavior is especially problematic in highvelocity environments in which strategic change is important for maintaining alignment with a changing environment, which can pose a significant threat to firms' continued performance (Kraatz and Zajac, 2001).

The combination of slack in financial resources with constraints in human resources (Figure 1: quadrant II) is expected to provide the best of two worlds. Specifically, the buffers of easily redeployable financial resources increase firms' ability to react quickly to changes in the environment (George, 2005; Voss et al., 2008). At the same time, constraints in human resources 
keep entrepreneurs vigilant and reduce the overoptimistic and complacent behavior found in resource-rich firms (Stevenson and Gumpert, 1985). ${ }^{1}$

In sum, we expect that constraints in certain resources will need to be compensated by abundance in others. As such, firms that are characterized by selective constraints will perform better relative to those that are characterized by parallel resource constraints. However, not all selective resource constraints are the same. Firm performance is expected to be higher when firms combine slack in unabsorbed financial resources with constraints in absorbed and "sticky" human resources. Thus,

Hypothesis 2: Firm performance will be higher when firms experience selective resource constraints in human resources (i.e., quadrant II) relative to selective resource constraints in financial resources (i.e., quadrant III) and parallel resource constraints (i.e., quadrant IV).

\section{Slack Bundles and Firm Performance: New Firms versus Later-Stage Firms}

Bundles of slack resources are unlikely to operate independently of a firm's stage of development. New firms and later-stage firms have different resource needs and resource management challenges (Sirmon et al., 2011). Paralleling prior research (McDougall and Oviatt, 1996; Zahra, 1996; Zahra et al., 2002), we define firms as new when they are eight years old or less and as later-stage when they are more than eight years old. The general premise of the resource constraints literature holds for both new and later-stage firms: firms characterized by resource constraints (Figure 1: quadrants II, III and IV) will exhibit higher performance relative to firms characterized by parallel resource abundance (Figure 1: quadrant I) - in part because of the less efficient use of resources in the latter group of firms. However, the resource constraints literature also suggests that certain types of constraints may not be viable as firms age. 
Specifically, as firms become older, the resource constraints literature posits that it is difficult to keep operating under parallel resource constraints (Figure 1: quadrant IV). Some firms clearly have an impressive ability to perform well without possessing the diverse set of resources that other firms consider to be essential (Starr and MacMillan, 1990). As firms continue to be confronted by multiple constraints, however, the lack of focus and routines in these firms combined with the continued pursuit of new opportunities without consideration of the firms' historical competencies and commitments (Baker and Nelson, 2005) is expected to result in "an unordered and disharmonious mixture of capabilities" (Selznick, 1957, p. 144), which will eventually hamper firm performance (Kraatz and Zajac, 2001). When firms are unable to shift from experiencing constraints in multiple domains to selective constraints, they often become so enmeshed in the communities they created that they are both unable to realize profits within them and unable to exploit opportunities from outside of them (Baker and Nelson, 2005; Porac et al., 1989).

In sum, although having low levels of financial and HR slack (i.e., parallel resource constraints) is beneficial for new firms' performance, this bundle is expected to be less valuable for firms in later stages of development. As firms develop, Baker and Nelson (2005) argue that they must develop towards selective constraints in inputs, which allows them to generate more efficient business routines, permitting them to realize more profits. Thus,

Hypothesis 3: Firm performance will benefit more from parallel resource constraints (i.e., quadrant IV) in new firms relative to firms in later stages of development.

\section{Slack Bundles and Firm Survival}


So far, our theorizing has focused on how bundles of slack resources affect firm performance. However, firm performance and survival represent two conceptually distinct outcomes, and their relationship is complex (Gimeno et al., 1997): performance does not guarantee survival, and survival does not guarantee performance. As such, it is possible that those bundles that are associated with higher performance are also the riskiest for firm survival. Scholars disagree on the relationship between resources and survival, however. A number of scholars argue that firms with fewer resources are more likely to fail relative to firms with more resources (Brüderl and Schüssler, 1990; Cooper et al., 1994). Others indicate that firms are able to survive and function with a bare minimum of resources (Baker and Nelson, 2005) and that the survival advantages bestowed by more resources are less relevant, particularly for firms in technology-based industries (Agarwal and Audretsch, 2001).

Consistent with the resource constraints literature, we argue that firms with resource constraints are not necessarily at a disadvantage relative to firms with parallel resource abundance (Baker and Nelson, 2005). Firms that combine slack in one type of resource with constraints in another type of resource (i.e., firms with selective resource constraints) may be sufficiently buffered against external shocks and internal disruptions (Thompson, 1967). For instance, firms with slack in financial resources but constraints in human resources (Figure 1: quadrant II) are unlikely to experience liquidity problems - one of the main factors that drive entrepreneurial firms into bankruptcy (e.g., Laitinen, 1992). Additionally, firms with HR slack but constraints in financial resources (Figure 1: quadrant III) can resort to a variety of bootstrapping techniques - techniques that allow entrepreneurs to access resources at minimal (or no) cost or allow entrepreneurs to access resources without the need the raise new cash from traditional outside financiers, such as banks (Winborg and Landström, 2001). Harrison et al. (2004) show that bootstrapping techniques - such as using special deals for access to hardware, 
customer-funded R\&D, working from home and prepaid licenses, royalties, advances from customers - are heavily used in the software industry. Moreover, a significant buffer of human resources makes it socially less acceptable for firms to go out of business, which is expected to increase the support of a firm's community. Wren and Storey (2002), for instance, show that a firm's probability of receiving publicly subsidized "soft" business support increases (at a decreasing rate) as its HR base increases, which benefits a firm's survival probability.

Resource constraints theorists further suggest that firms can address multiple constraints in multiple domains (Figure 1: quadrant IV), for instance, through strategies such as begging, borrowing and scavenging to obtain access to underutilized resources from their social relationships (Starr and MacMillan, 1990). However, these same scholars also indicate that although entrepreneurs may use their social contacts to access resources without owning the resources, the opportunity costs and risks of such strategies may be high given the lack of formal commitments, uncertainty, and possibilities of opportunistic behavior (Starr and MacMillan, 1990). For instance, resource providers with whom firms have no formal contracts may decide from one day to another that they are no longer willing to provide resources under the same conditions or may refrain from providing resources altogether. Overall, this possibility suggests that firms with parallel resource constraints might be able to address the constraints but that the strategies used do not necessarily reduce (and indeed may even increase) their vulnerability to internal disruptions and external shocks. Thus,

Hypothesis 4: Firm survival will be lower when firms experience parallel resource constraints (i.e., quadrant IV) relative to selective resource constraints (i.e., quadrants II and III) and parallel resource abundance (i.e., quadrant I).

\section{METHODS}




\section{Sample and Data Sources}

The data for this paper come from the VICO consortium-a group of nine European research teams. This consortium constructed a large longitudinal data set to provide a detailed picture of the financing and development of technology-based entrepreneurial firms in seven European countries: Belgium, Finland, France, Germany, Italy, Spain and the UK. Technology-based entrepreneurial firms were identified as firms that (a) were less than 10 years old in 1994 or founded afterwards; (b) operate in high-tech sectors, including aerospace, biotech, energy, ICT manufacturing, Internet, nanotech, pharmaceutical, robotics, software, telecom, web publishing and other R\&D; and (c) were independent at startup. The VICO data set comprises 8,370 technology-based entrepreneurial firms and covers data from 1994 until 2009. The data set also includes firms that left the sample due to bankruptcy, acquisitions or buy-outs between 1994 and 2009 (see Bertoni and Martí (2011) for more details on the VICO data set).

Research teams in each country collected data from multiple sources. Financial and employment data come from Amadeus, a database that includes high-quality comparable information for public and private firms across Europe (Faccio et al., 2011). These data were validated and updated with data from country-specific databases, such as Bel-first for Belgium (Vanacker et al., 2013) and Fame for the UK (Brav, 2009), which often comprise more detailed data. Ownership data, including venture capital (VC) backing, were obtained from the Thomson ONE (former VentureXpert) and Zephyr databases, which are extensively used in VC research (De Clercq and Dimov, 2008). Patent data come from PATSTAT, a database that provides a snapshot of the EPO master documentation database with worldwide coverage on patents, including bibliographic data, citations and family links (Devigne et al., 2013). Each local team initially checked the data for reliability and internal consistency. Next, the data were regularly 
sent to a central data collection unit, which ensured that information across countries was consistent and comparable.

From the VICO data set, we first select firms that operate in the ICT industry $(6,625$ firms remain). Focusing on firms that operate in one industry limits the unobserved heterogeneity among firms that results from variance in industry conditions. By focusing in this way, we also address a call by George (2005) for studies that examine multiple forms of slack in a single industry. Second, we exclude firms from Germany because we lack basic financial data for German firms (5,550 firms remain). In Germany, failure to disclose financial accounts is not a punishable offence for small- and medium-sized firms, which explains our lack of basic data. Finally, our regression approach requires firms to have complete data for at least two years. These selection filters result in a final sample of 4,715 European firms (from Belgium, Finland, France, Italy, Spain and the UK) that were active in the ICT industry between 1994 and 2009, covering 30,669 firm-year observations. Appendix A provides an overview of the sample by founding period, year, country and ICT sub-industries.

\section{Dependent Variables}

Our theory posits that different bundles of slack resources will differently influence firm performance and survival. Firm performance is operationalized as Earnings Before Interest, Taxes, Depreciation and Amortization (EBITDA) scaled by total assets. We use EBITDA instead of net income to minimize the effect of accounting (e.g., depreciations) and tax treatments on our results. EBITDA is scaled by total assets to make it comparable for firms of different sizes and to reduce heteroskedasticity concerns (Brav, 2009). ${ }^{2}$ To study firm survival, we examine the probability that a firm will exit over the next year, conditional on it having survived up to the current year. Firms may exit the sample if they shut down, stop operating as separate entities 
because of merger or acquisitions, or are stripped of workers and assets and essentially become "empty shells". As described in Appendix B, our results remain virtually identical when we use alternative measures of firm performance and survival.

\section{Independent Variables}

To calculate slack, we use financial ratios, as has been done in prior work (e.g., Bradley et al., 2011a,b; George, 2005; Mishina et al., 2004; Mousa and Reed, 2013). Motivated by our theory development, we focus on bundles of financial (available) slack and HR slack. ${ }^{3}$

Because cash resources represent the most easily redeployable resources and provide managers with the greatest discretion in allocation to alternative uses (George, 2005), we measure financial slack as the amount of cash available within a firm scaled by total assets (Kim and Bettis, 2014; Vanacker et al., 2013). From this ratio, we subtract the median ratio of cash to total assets for all firms operating in the same ICT sub-industry (i.e., ICT manufacturing, telecom, web publishing, Internet and software) and country. Our approach is consistent with prior (single country) research that has defined slack as excess resources held by firms relative to industry norms (Bromiley, 1991; George, 2005).

$H R$ slack is measured as employment cost relative to sales (Bradley et al., 2011b), from which we subtract the median ratio of employment cost to sales for all firms in the same subindustry and country in which the focal firm operates. Prior work has used similar definitions of HR slack, such as the number of employees to sales adjusted for industry norms (e.g., Mellahi and Wilkinson 2010; Mishina et al., 2004). We use employment cost rather than the number of employees as the basis for our calculation of HR slack. Empirically, employment cost is better completed for the private firms in our sample and is highly correlated with the number of employees (at 0.97; p < 0.01). Employment cost is hence a good proxy for the number of 
employees in a firm. Theoretically, employment cost captures both the quantity and the quality of human resources (Vanacker et al., 2013).

We test for the hypothesized effects of different bundles of financial and HR slack on firm outcomes by using two distinct approaches (e.g., Sirmon et al., 2010). First, we utilize dummy variables to identify the firms represented by the four quadrants presented in Figure 1. For this purpose, we identify firms as having financial (HR) slack when their cash-to-total asset ratio (employment-cost-to-sales ratio) is above the sub-industry and country median values. Firms are identified as experiencing constraints in financial (human) resources when these ratios are below the sub-industry and country median values. Second, we estimate models with financial slack and its squared term, HR slack and its squared term and the interaction between financial and HR slack. $^{4,5}$

\section{Control Variables}

We control for a variety of variables that are standard controls in studies on the performance effects of slack resources and variables that are specific to our context.

We include a number of firm-level controls. Firm size is expected to influence both the performance potential of firms and their ability to accumulate slack (George, 2005). We control for firm size, measured as the natural logarithm of sales plus one. Because slack is timedependent in its accumulation, we control for firm age (Sharfman et al., 1988). Firm age is measured as the years since incorporation. Firms with growth ambitions require more (different) resources (Sapienza et al., 2003). The intangible assets ratio, defined as the ratio of intangible assets (including $\mathrm{R} \& \mathrm{D}$ expenses and the value of patents, trademarks and brands) to total assets, is used as a measure for firms' growth potential (Villalonga, 2004). We also control for firms' knowledge intensity (Vanacker et al., 2013) by including the natural logarithm of the cumulative 
number of patents applied for (plus one). The number of patents applied for is discounted using a 0.15 discount factor, as is common in the literature on innovation economics (Griliches, 1992). The mere presence of a VC investor allows portfolio firms to realize more with a given set of slack resources relative to firms without VC backing (Vanacker et al., 2013). We therefore include a $V C$ dummy that is equal to 1 if a firm is backed by at least one $\mathrm{VC}$ investor and zero otherwise. Further, we control for other types of slack. Potential slack is measured as the debt-tototal-assets ratio (Kim and Bettis, 2014), adjusted for sub-industry and country norms. We multiply this measure by -1 so that higher values indicate more potential slack. We also include the squared term to capture any curvilinear effect. Recoverable slack is defined as inventories to sales, adjusted for sub-industry and country norms (Bourgeois and Singh, 1983; Steensma and Corley, 2001). ${ }^{6}$ We also include the squared term to capture any curvilinear effect. Finally, to account for possible persistence in firm performance, we included lagged performance. Adding the lagged dependent variable has also been recommended as a means to control for unobserved heterogeneity (Heckman and Borjas, 1980).

In all models, we further control for industry, country and year effects. Specifically, industry fixed effects control for subtle differences within the ICT industry. The country fixed effects control for potential country effects, including unmeasured cultural differences and differences in accounting requirements. The year fixed effects control for the effects of any general economic trend.

To minimize concerns of reverse causality, all independent and control variables are lagged by one period.

\section{Method of Analysis}


When using longitudinal data, scholars need to account for correlations between observations from the same firm when estimating regression parameters; otherwise, they can make incorrect inferences. We use the generalized estimating equation (GEE) approach to estimate efficient and unbiased regression parameters for longitudinal data (see Ballinger, 2004, for a detailed discussion). Relative to fixed- and random-effects models, the GEE model provides more consistent and robust regression parameters when autocorrelation because of non-independence is present (Ndofor et al., 2011). In addition, GEE models can be used for a range of dependent variables, including those that are normally distributed (i.e., firm performance) and binary dependent variables (i.e., firm survival). ${ }^{7}$ Applications of the GEE technique are widely available in the literature (e.g., Ballinger, 2004; Haveman and Nonnemaker, 2000).

\section{RESULTS}

Table I provides an overview of the means, standard deviations, minima, maxima and correlations between the variables used in the empirical models. Table II provides additional descriptive statistics on the average levels of slack, performance and exit rates for each of the four bundles of slack depicted in Figure 1.

\section{INSERT TABLE I AND TABLE II ABOUT HERE}

Table III reports the results from the GEE regression models that examine the relationship between distinct slack bundles and firm performance. In Model 1, we use dummies that represent the different resource bundles (parallel resource abundance is the reference category). In Model 2, we take a different approach by including the linear and quadratic effects of financial and HR slack and the interaction between both. Models 3 and 4 are equivalent to Models 1 and 2 but focus on the subsample of new firms, whereas Models 5 and 6 focus on the subsample of laterstage firms. 


\section{INSERT TABLE III ABOUT HERE}

The control variables show that larger firms have lower performance ratios, and older firms exhibit higher performance. Firms with more potential slack exhibit lower performance. Firms with more recoverable slack also exhibit lower performance, especially at high levels of recoverable slack. Moreover, firms that were more profitable in the past are likely to be more profitable in the future; hence, performance is persistent.

Our results support Hypothesis 1: firms with resource constraints in one or multiple domains perform better than firms with parallel resource abundance. As shown in Model 1, firms with selective constraints in human resources but with slack in financial resources (Figure 1: quadrant II) exhibit higher performance $(\beta=0.025 ; \mathrm{p}<0.01)$ relative to firms with parallel resource abundance. Firms with selective constraints in financial resources but with HR slack (Figure 1: quadrant III) exhibit higher performance $(\beta=0.012 ; p<0.01)$ relative to firms with parallel resource abundance. Finally, firms with parallel resource constraints (Figure 1: quadrant IV) exhibit higher performance $(\beta=0.011 ; p<0.01)$ relative to firms with parallel resource abundance. Our results further support Hypothesis 2: firms that combine resource constraints in human resources with slack in financial resources (Figure 1: quadrant II) exhibit the highest performance. Indeed, whereas both firms with selective constraints in financial resources and firms with parallel resource constraints have an EBITDA-to-total assets ratio that is approximately 1.1-1.2 percentage points higher than firms with parallel resource abundance, firms with selective constraints in human resources have a 2.5-percentage-point higher ratio. The differences between firms with selective constraints in human resources and those with constraints in financial resources or parallel resource constraints are significant (all at $\mathrm{p}<0.01$ ).

Model 2 confirms the existence of quadratic relationships between financial (HR) slack and firm performance, which is consistent with prior research. Model 2 also shows a negative and 
significant interaction effect between financial and HR slack $(\beta=-15.991 ; \mathrm{p}<0.01)$. Figure 2 provides a rich visualization of the combined effects of financial slack and HR slack. Firm performance is plotted according to distinct combinations of financial (x-axis) and HR (y-axis) slack. The figure shows that increasing levels of financial slack have a largely positive effect on firm performance when HR slack is low but that increasing levels of financial slack have a largely negative effect on firm performance when HR slack is high. Figure 2 also shows that firms that combine high levels of financial slack with low levels of HR slack exhibit the highest performance. These findings provide additional supporting evidence for Hypotheses 1 and 2.

\section{INSERT FIGURE 2 ABOUT HERE}

Our results support Hypothesis 3: parallel resource constraints only provide a performance advantage for new firms but not for later-stage firms. The coefficient of parallel resource constraints in Model $3(\beta=0.014 ; \mathrm{p}<0.01)$ is positive and significant for new firms, but in Model 5, the coefficient is no longer significantly different from zero for later-stage firms. Interestingly, firms with selective constraints in human resources but slack in financial resources outperform the other bundles in both the subsample of new firms $(\beta=0.032 ; p<0.01)$ and that of firms at later stages of development $(\beta=0.016 ; p<0.01)$. It is also important to note in Model 5 that for firms in later stages of development with selective constraints in financial resources and slack in human resources $(\beta=0.007 ; \mathrm{p}=0.111)$, the performance advantage is no longer statistically significant at traditional levels, although it is close to being marginally significant. A comparison of the interaction between financial and HR slack in Models 4 and 6 shows that this interaction is more negative for new firms relative to later-stage firms $(\mathrm{p}<0.01)$. A graphical visualization (unreported owing to space considerations) of Models 4 and 6 confirms that firms with selective constraints in human resources but slack in financial resources outperform the other bundles for both new and later-stage firms. 
Table IV reports the GEE discrete-time survival regressions that examined the relationships between distinct slack bundles and firm exit, where negative and significant coefficients imply that firm exit rates are lower (survival rates are higher) for larger values of the independent variables and controls. In Model 1, we use dummies that represent the different resource bundles (parallel resource abundance is the reference category). In Model 2, we take a different approach by including the linear and quadratic effects of financial and HR slack and the interaction between both. Models 3 and 4 are equivalent to Models 1 and 2 but focus on the subsample of new firms, and Models 5 and 6 focus on the later-stage firms.

\section{INSERT TABLE IV ABOUT HERE}

The control variables indicate that larger, older firms and more profitable firms have lower exit rates. Interestingly, although potential and recoverable slack hamper financial performance, they foster firm survival.

Our results support Hypothesis 4: firms with parallel resource constraints have higher exit rates (lower survival rates) relative to firms with parallel resource abundance and selective resource constraints. Model 1 shows that firms with parallel resource constraints have higher exit rates (at $\mathrm{p}<0.01)$ relative to firms with parallel resource abundance. Interestingly, there are no significant differences in the exit rates of firms with selective resource constraints relative to firms with parallel resource abundance. Our findings hold in the subsamples of both new (Model 3) and later-stage (Model 5) firms, where firms with parallel resource constraints have significantly higher exit rates (all at $\mathrm{p}<0.05$ ). Model 2 shows that financial slack has a negative (but decreasing) effect on firm exit. HR slack also has a negative (but decreasing) effect on firm exit. Interestingly, although HR slack increases firm survival rates, it decreases firm financial performance. The interaction effect between financial and HR slack on firm exit rates is positive and statistically significant (for the full sample at $\mathrm{p}<0.10$ and later-stage firms at $\mathrm{p}<0.05$ but 
not at traditional levels for new firms). A graphical visualization of Model 2 in Figure 3 shows that firms with parallel resource constraints are indeed confronted with the highest exit rates (lowest survival rates). These findings emerge from the subsamples of new firms (Model 4) and later-stage firms (Model 6) as well.

\section{INSERT FIGURE 3 ABOUT HERE}

We performed a number of tests that demonstrate the robustness of our results. These robustness tests are described in Appendix B.

\section{DISCUSSION}

The results of this study enrich an ongoing debate on the importance of slack resources and provide a more complex picture of the effects of slack resources on firm outcomes. Our theoretical and empirical focus on the effects of distinct bundles of slack resources on firm performance and survival, and their temporal dynamics, yields important new insights. We explore these new insights and their implications for the slack literature and resource-based literature in more detail below.

\section{Implications for Slack Literature}

Prior research has argued that the relationship between an isolated type of slack and firm performance is inverted U-shaped because too little of this slack type causes constrained decision making and too much facilitates inefficient behavior (Tan and Peng, 2003). Because these studies focus on an isolated slack resource, the view of classic resource-based theorists (i.e., "more is better") is incompatible with the view of resource constraints theorists (i.e., "less is more"). The solution provided by extant research is that "an intermediated level of slack is optimal" (Nohria and Gulati, 1997, p. 603). However, studies still provide ambiguous results, for example, 
showing positive (George, 2005), curvilinear (Bradley et al., 2011a) and negative (Natividad, 2013) relationships between financial slack and firm performance.

Our study provides a novel perspective that reframes the ongoing debate on the performance effect of slack. Although the mechanisms we propose are similar to those of prior research, we argue that these mechanisms operate at the higher level of a firm's bundle of slack resources rather than at the level of an isolated slack resource. Specifically, inefficient behavior (constrained decision making) is more likely to arise when firms combine resource slack (resource constraints) in too many domains. In our perspective, classic resource-based and resource constraints viewpoints are not incongruent and firms should not necessarily combine intermediate levels of all types of resources. On the contrary, firms can combine "more" of a specific resource with "less" of another resource, and our empirical evidence shows that it is exactly this combination that leads to superior performance. Our findings are consistent with creativity research (e.g., Moreau and Dahl, 2005), which argues that individuals are more creative when they are confronted with some input constraints, making them more effective at meeting specific goals.

Our perspective further provides an explanation for the mixed findings on the performance effects of slack at the level of an individual type of slack. In our perspective, even in a homogenous set of firms (for example, a sample of new ICT firms), very different types of relationships (i.e., positive, curvilinear or negative) can emerge between a specific type of resource slack and firm performance. When firms are conceived as bundles of resources, resources may interact with one another and enhance or suppress each other's effects on performance (Black and Boal, 1994). Although this has been underappreciated in prior research, our empirical evidence indeed shows that fundamentally different relationships emerge between specific types of resource slack and firm performance, depending on the level of other types of 
slack (see Figure 2 for a graphical visualization). Overall, our study highlights the importance of investigating the performance implications of slack at the level of a firm's bundle of slack resources rather than studying the effects of isolated slack resources, thereby emphasizing important interdependencies between these resources.

\section{Implications for Resource-Based Literature}

Extant resource-based work has largely focused on isolated resources, including human resources, social capital and technological resources, because these resources are valuable, rare, inimitable, and nonsubstitutable (Barney, 1991); hence, they can lead to a sustainable competitive advantage. At the same time, limited attention has been paid in RBV to more generic resources, such as financial capital, because generic resources are unlikely to provide firms with a sustainable competitive advantage (Ireland et al., 2003). Building on this research, one could argue that managers should simply build resource bundles that comprise abundant valuable, rare, and inimitable resources that cannot be substituted, such as human resources. They should pay less attention to accumulating more generic resources, such as financial resources; although firms may have these, they are unlikely to provide a sustainable competitive advantage. Our results differ from such RBV propositions. Specifically, we find that firms that combine abundant generic financial resources with constraints in human resources exhibit superior performance. Our results have at least two important implications for resource-based theory.

First, current resource-based work, because of its common focus on isolated resources, ignores the possibility that more generic resources may allow firms to acquire other more strategic resources when needed (Lee et al., 2001). Sustainable competitive advantages may then result not only from possessing resources with particular characteristics (Barney, 1991) but also from managers' ability to quickly pursue new opportunities and buy in to the most suitable 
strategic resources when they are needed. As Penrose (1959) suggested, resources by themselves may not be sufficient to generate sustainable competitive advantages; how managers use their resources may be equally important. Overall, although simply possessing generic resources cannot drive a sustainable competitive advantage either, these resources may allow managers to pursue unique strategies that provide their firms with sustainable competitive advantages.

Second, our study does not suggest that managers should avoid attracting less generic resources (for example, better-educated and better-trained human resources) to fulfill normal resource needs. However, our study does suggest that managers should be careful when integrating buffers of less generic, absorbed resources in their resource bundles because such resource bundles may constrain their firms' strategic flexibility (Mishina et al., 2004). These findings suggest that there may be an important distinction between the characteristics of the resources firms should attract to fulfill their "normal" resource needs and the characteristics of the resources firms may want to keep in "excess" for when unexpected opportunities or environmental shifts occur.

Finally, by demonstrating the advantages and disadvantages related to particular resource bundles at different stages in the firm life cycle, we provide crucial extensions that cross-validate the theoretical value of resource-based theories (e.g., Armstrong and Shimizu, 2007; Priem and Butler, 2001). We show that there are few resource bundles that provide performance benefits at different stages in the firm life cycle without hampering firm survival. However, there are many resource bundles that provide no specific performance benefits, only provide performance benefits at a particular stage in the life cycle and even reduce firm survival prospects. In addition, managers are confronted with important resource management challenges. Even when firms hold an "optimal" resource bundle, natural pressures - such as the age-dependent nature of slack accumulation (Sharfman et al., 1988) or environmental shocks that make previously accumulated 
strategic resources obsolete (Leonard-Barton, 1992) - may drive them towards suboptimal bundles. These findings provide an explanation for why sustainable competitive advantages are often short-lived (Wiggins and Ruefli, 2005).

\section{Limitations and Avenues for Further Research}

This study is not without limitations, some of which suggest avenues for future research. First, theoretical tractability pushed us to focus on bundles of slack resources for two types of resources (financial and human). Although all firms require some of both, they do not represent the complete set of resources that firms require to start up and grow. Other types of slack resources include operational, customer-related and innovational slack (Mousa and Reed, 2013; Voss et al., 2008). Of particular interest for future research is the question of how far resource constraints in multiple domains can stretch and whether the "optimal" combination of resource abundance and scarcity is contingent upon firm and environmental characteristics.

Second, our measure of HR slack, or excess numbers of employees on the payroll, is rather crude. Specifically, we define HR slack as employment cost on sales adjusted for industry and country norms - a measure that is virtually identical to (and hence highly correlated with) measures used by other scholars, such as number of employees on sales adjusted for industry norms (e.g., Mishina et al., 2004). However, exploring the role of HR slack more fully, for instance, by using more fine-grained measures of HR slack that indicate if employees within the firm possess the necessary critical human capital resources would be an enriching avenue for further inquiry.

Third, our study focuses on the direct link between slack resources and firm performance but does not provide direct evidence for the mechanisms through which different bundles of slack resources influence performance and survival. In our theorizing, largely drawing on resource 
constraints theories, we suggested a number of mechanisms through which different bundles of slack resources are expected to influence performance. These mechanisms include differences in the willingness and ability of firms with different slack bundles to act upon new opportunities (and related changes in the external environment) and differences in entrepreneurial creativity to make do with the limited resources at hand. Many of these mechanisms are difficult to measure and would require us to supplement our database with survey evidence (e.g., Bradley et al., 2011b). Future research might collect finer-grained data and study the factors that mediate the relationship between bundles of slack resources and firm outcomes.

Finally, although our robustness checks demonstrate that our findings hold in an independent sample of other technology-based firms and in subsamples that comprise different institutional contexts, future research might establish whether our results generalize to a more diverse set of industries (such as, for instance, low-tech industries) and more diverse institutional contexts (such as, for instance, developing economies). Replicating this study in other industries and institutional contexts would be of interest to further establish the generalizability of our results. Moreover, scholars may study the impact of distinct bundles of slack resources on firm innovation. Emerging areas in innovation research, such as jugaad innovation (George et al., 2012; Radjou et al., 2012), suggest that entrepreneurs can also be innovative under conditions of poverty.

\section{Policy and Managerial Implications}

Our distinction between the resource bundles and conditions that lead to performance advantages and those that do not carries important policy and managerial implications. Technology-based entrepreneurial firms are widely regarded as important contributors to innovation, employment creation and economic growth in our modern knowledge-based economies. EU policy-makers, 
however, often talk of a "European paradox": although the scientific performance of European technology-based firms is excellent, their commercial performance has deteriorated (European Commission, 1995). Our findings suggest that parallel constraints in financial and human resources negatively affect the viability of technology-based firms. Governments play a key task in stimulating the availability of financial resources. Governments can also address the "sticky" nature of HR slack, which often damages firm performance, by optimizing labor laws and stimulating employee education and training for technology-based firms.

However, our study also shows that it is important for early-stage entrepreneurs to recognize that the solution for confronting many of the challenges facing them is not necessarily "having more resources". In a similar vein, managers in later-stage firms that face continuous pressures to remove all "inefficiencies" and build lean firms should be careful in significantly reducing all buffers. Combining financial resource abundance with resource constraints in "sticky" human resources is often optimal for firm performance and does not weaken the survival prospects of technology-based firms. It also suggests that entrepreneurs and managers should carefully craft their HR strategies, with particular attention to the questions when to attract human resources and how to prevent current human resources from becoming excessively sticky, thereby reducing firms' adaptability to opportunities and threats in their environments.

\section{Conclusion}

Taken together, this study provides new insights into the complex relationships between bundles of slack resources, firm performance and firm survival and the temporal nature of these relationships. The results suggest that firms that combine slack in unabsorbed financial resources with constraints in absorbed human resources exhibit superior firm performance without hampering their survival prospects. 


\section{NOTES}

${ }^{1}$ It is not because firms with slack in financial resources and constraints in human resources (Figure 1: quadrant II) pursue new opportunities that they automatically evolve towards a different resource bundle (such as quadrants I, III or IV). As firms consume part of their financial slack to pursue new opportunities, they may still have financial slack left, or at the same time build up additional financial slack from their existing (and new) operations. As another example, it is not because firms use their financial slack to pursue new opportunities and hire new employees that they will necessarily develop HR slack. This is true because HR slack is measured relative to human resource demands, and as firms pursue new opportunities, their demands for human resources may also be higher, so that HR slack may not develop.

${ }^{2}$ EBITDA scaled by total assets is highly correlated with alternative performance measures, such as gross profit scaled by total assets $(0.879 ; \mathrm{p}<0.001)$ and EBIT scaled by total assets $(0.960 ; \mathrm{p}<0.001)$.

${ }^{3}$ By focusing on bundles of financial and HR slack, it may appear that we ignore some other forms of slack used in prior research. However, as discussed in more detail in the 'control variables' section, we control for other types of slack, including potential (i.e., debt capacity) and recoverable (i.e., financial resources that are currently absorbed in inventories) slack.

${ }^{4}$ We do not include nonlinear interaction effects (i.e., financial slack squared x HR slack, financial slack x HR slack squared and financial slack squared $\mathrm{x}$ HR slack squared) in our reported regression models. Empirically, these nonlinear interaction effects were never significant.

5 The approach with the dummy variables is easy to interpret. Moreover, it captures the essence of our configurational approach, in which we argue that bundles of slack resources are driving firm performance and survival rather than individual slack resources. The dummy variable approach, however, requires arbitrary cut-off values. Using the approach with the continuous slack variables, their squared terms and interaction terms stays closer to the original approach in slack research, where scholars have argued that there exists an optimal level of slack. The interaction effect, however, is more difficult to interpret. For instance, a negative interaction between financial slack and HR slack indicates that the value of financial slack is less positive for firms with higher levels of HR slack. However, it does not indicate whether it is optimal to combine high levels of financial slack with low levels of HR slack or vice versa. Moreover, interaction terms are challenging to interpret when the dependent variable is binary 
(Hoetker, 2007), such as in models with survival as the dependent variable. These considerations explain our use of both approaches.

${ }^{6}$ Other scholars have used selling, general and administrative (SG\&A) expenses divided by firm sales as a measure of recoverable slack (Bromiley, 1991; Singh, 1986), especially in the context of public firms. Unfortunately, we do not have such data for the private firms we study. However, as indicated by Bradley et al. (2011a), SG\&A expenses are actually "lumpy" and less recoverable. We therefore used inventories on sales as an alternative proxy for recoverable slack (Bourgeois and Singh, 1983; Steensma and Corley, 2001).

${ }^{7}$ In survival analysis, continuous-time methods (such as a Cox regression) are appropriate when researchers know the exact times at which events (exits in our case) occur (Allison, 1995). However, we rely on yearly data and know only the year of exit, which makes it more appropriate to use discrete-time methods (Allison, 1995). We use GEE discrete-time survival models with a complementary log-log-link function. For a similar approach and more detailed description, see Echambadi et al. (2006) and Haveman and Nonnemaker (2000).

\section{REFERENCES}

Agarwal, R. and Audretsch, D. B. (2001). 'Does entry size matter? The impact of the life cycle and technology on firm survival'. The Journal of Industrial Economics, 49, 21-43.

Allison, P. D. (1995). Survival Analysis using the SAS System. Cary, NC: SAS Institute.

Armstrong, C. E. and Shimizu, K. (2007). 'A review of approaches to empirical research on the resource-based view of the firm'. Journal of Management, 33, 959-86.

Baker, T. and Nelson, R. E. (2005). 'Creating something from nothing: resource construction through entrepreneurial bricolage'. Administrative Science Quarterly, 50, 329-66.

Ballinger, G. (2004). 'Using generalized estimating equations for longitudinal data analysis'. Organizational Research Methods, 7, 127-50.

Barney, J. B. (1991). 'Firm resources and sustained competitive advantage'. Journal of Management, 17, 99-120.

Bertoni, F. and Martí, J. (2011). Financing Entrepreneurial Ventures in Europe: the VICO dataset. Available at: http://ssrn.com/abstract=1904297 (accessed 24 October 2014).

Bhide, A. (1992). 'Bootstrap finance: the art of start-ups'. Harvard Business Review, 70, 109-17.

Black, J. A. and Boal, K. B. (1994). 'Strategic resources: traits, configurations and paths to sustainable competitive advantage'. Strategic Management Journal, 15, 131-48. 
Bourgeois, L. J. (1981). 'On the measurement of organizational slack'. Academy of Management Review, 6, 29-39.

Bourgeois, L. J. and Singh, J. V. (1983). 'Organizational slack and political behavior within top management groups'. Academy of Management Proceedings, 43-9.

Bradley, S. W., Shepherd, D. A. and Wiklund, J. (2011a). 'The importance of slack for new organizations facing “tough" environments'. Journal of Management Studies, 48, 1071-97.

Bradley, S. W., Wiklund, J. and Shepherd, D. A. (2011b). 'Swinging a double-edged sword: the effect of slack on entrepreneurial management and growth'. Journal of Business Venturing, 26, 53754.

Brav, O. (2009). 'Access to capital, capital structure, and the funding of the firm'. Journal of Finance, 64, 263-308.

Bromiley, P. (1991). 'Testing a causal model of corporate risk taking and performance'. Academy of Management Journal, 34, 37-59.

Brüderl, J. and Schüssler, R. (1990). 'Organizational mortality: the liabilities of newness and adolescence'. Administrative Science Quarterly, 35, 530-47.

Cooper, A., Gimeno-Gascon, J. and Woo, C. (1994). 'Initial human and financial capital as predictors of new venture performance'. Journal of Business Venturing, 9, 371-95.

Cyert, R. M. and March, J. G. (1963). A Behavioural Theory of the Firm. New York, Englewood Cliffs: Prentice-Hall.

Daniel, F., Lohrke, F. T., Fornaciari, C. J. and Turner, J. R. A. (2004). 'Slack resources and firm performance: a meta-analysis'. Journal of Business Research, 57, 565-74.

Danneels, E. (2008). 'Organizational antecedents of second-order competences'. Strategic Management Journal, 29, 519-43.

Debruyne, M., Frambach, R. T. and Moenaert, R. (2010). 'Using the weapons you have: the role of resources and competitor orientation as enablers and inhibitors of competitive reaction to new products'. Journal of Product Innovation Management, 27, 161-78.

De Clercq, D. and Dimov, D. (2008). 'Internal knowledge development, and external knowledge access in venture capital investment performance'. Journal of Management Studies, 45, 585-612.

Devigne, D., Vanacker, T., Manigart, S. and Paeleman, I. (2013). 'The role of domestic and crossborder venture capital in the growth of portfolio companies'. Small Business Economics, 40, 553-73.

Dolmans, S. A., van Burg, E., Reymen, I. M. and Romme, A. G. (2014). 'Dynamics of resource slack and constraints: resource positions in action’. Organization Studies, 35, 511-49.

Echambadi, R., Campbell, B. and Agarwal, R. (2006). 'Encouraging best practice in quantitative management research: an incomplete list of opportunities'. Journal of Management Studies, 43, 180120. 
European Commission (1995). Green Paper on Innovation. Available at: http://europa.eu/documents/comm/green_papers/pdf/com95_688_en.pdf (accessed 24 October 2014).

Faccio, M., Marchica, M. and Mura, R. (2011). 'Large shareholder diversification and corporate risktaking'. Review of Financial Studies, 24, 3601-41.

Fichman, M. and Levinthal, D. A. (1991). 'Honeymoons and the liability of adolescence: a new perspective on duration dependence in social and organizational relationships'. Academy of Management Review, 16, 442-68.

Fitts, J. (2014). The Internet of things will change your company, not just your products. Available at: https://hbr.org/2014/10/the-internet-of-things-will-change-your-company-not-just-your-products

(accessed 24 October 2014).

Garud, R. and Karnoe, P. (2003). 'Bricolage versus breakthrough: distributed and embedded agency in technology entrepreneurship'. Research Policy, 32, 277-300.

George, G. (2005). 'Slack resources and the performance of privately held firms'. Academy of Management Journal, 48, 661-76.

George, G., McGahan, A. M. and Prabhu, J. (2012). 'Innovation for inclusive growth: towards a theoretical framework and a research agenda'. Journal of Management Studies, 49, 661-83.

Ghemawat, P. and Costa, J. E. R. I. (1993). 'The organizational tension between static and dynamic efficiency'. Strategic Management Journal, 14, 59-73.

Gilbert, B. A., McDougall, P. P. and Audretsch, D. B. (2006). 'New venture growth: a review and extension'. Journal of Management, 32, 926-50.

Gimeno, J., Folta, T. B., Cooper, A. C. and Woo, C. Y. (1997). 'Survival of the fittest? Entrepreneurial human capital and the persistence of underperforming firms'. Administrative Science Quarterly, 42, 750-83.

Goldenberg, J., Lehmann, D. R. and Mazursky, D. (2001). 'The idea itself and the circumstances of its emergence as predictors of new product success'. Management Science, 47, 69-84.

Greenley, G. E. and Oktemgil, M. (1998). 'A comparison of slack resources in high and low performing British companies'. Journal of Management Studies, 35, 377-98.

Greve, H. R. (2003). 'A behavioral theory of R\&D expenditures and innovations: evidence from shipbuilding'. Academy of Management Journal, 46, 685-702.

Griliches, Z. (1992). 'The search for R\&D spillovers'. Scandinavian Journal of Economics, 94, 2947.

Gruber, M., Heinemann, F., Brettel, M. and Hungeling, S. (2010). 'Configurations of resources and capabilities and their performance implications: an exploratory study on technology ventures'. Strategic Management Journal, 31, 1337-56.

Harrison, R. T., Mason, C. M. and Girling, P. (2004). 'Financial bootstrapping and venture development in the software industry'. Entrepreneurship \& Regional Development, 16, 307-33. 
Hamel, G. and Prahalad, C. K. (1993). 'Strategy as stretch and leverage'. Harvard Business Review, 71, 75-84.

Haveman, H. A. and Nonnemaker, L. (2000). 'Competition in multiple geographic markets: the impact on growth and market entry'. Administrative Science Quarterly, 45, 232-67.

Heckman, J. J. and Borjas, G. J. (1980). 'Does unemployment cause future unemployment: definitions, questions and answers from a continuous-time model of heterogeneity and state dependence'. Economica, 47, 247-83.

Heirman, A. and Clarysse, B. (2007). 'Which tangible and intangible assets matter for innovation speed in start-ups?'. Journal of Product Innovation Management, 24, 303-15.

Hoegl, M., Gibbert, M. and Mazursky, D. (2008). 'Financial constraints in innovation projects: when is less more?'. Research Policy, 37, 1382-91.

Hoetker, G. (2007). 'The use of logit and probit models in strategic management research: critical issues'. Strategic Management Journal, 28, 331-43.

Ireland, R. D., Hitt, M. A. and Sirmon, D. G. (2003). 'A model of strategic entrepreneurship: the construct and its dimensions'. Journal of Management, 29, 963-89.

Kim, C. and Bettis, R. A. (2014). 'Cash is surprisingly valuable as a strategic asset'. Strategic Management Journal, 35, 2053-63.

Kraatz, M. S. and Zajac, E. J. (2001). 'How organizational resources affect strategic change and performance in turbulent environments: theory and evidence'. Organization Science, 12, 632-57.

Laitinen, E. K. (1992). 'Prediction of failure of a newly founded firm'. Journal of Business Venturing, 7, 323-40.

Lecuona, J. R. and Reitzig, M. (2014). 'Knowledge worth having in "excess": the value of tacit and firm-specific human resource slack'. Strategic Management Journal, 35, 954-73.

Lee, C., Lee, K. and Pennings, J. M. (2001). 'Internal capabilities, external networks, and performance: a study on technology-based ventures'. Strategic Management Journal, 22, 615-40.

Leonard-Barton, D. (1992). 'Core capabilities and core rigidities: a paradox in managing new product development'. Strategic Management Journal, 13, 111-25.

Levinthal, D. A. and March, J. G. (1993). 'The myopia of learning'. Strategic Management Journal, 14, 95-112.

Love, G. E. and Nohria, N. (2005). 'Reducing slack: the performance consequences of downsizing by large industrial firms, 1977-93’. Strategic Management Journal, 26, 1087-108.

McDougall, P. P. and Oviatt, B. M. (1996). 'New venture internationalization, strategic change, and performance: a follow-up study'. Journal of Business Venturing, 11, 23-40.

Mellahi, K. and Wilkinson A. (2010). 'A study of the association between level of slack reduction following downsizing and innovation output'. Journal of Management Studies, 47, 483-508. 
Mishina, Y., Pollock, T. and Porac, J. (2004). 'Are more resources always better for growth? Resource stickiness in market and product expansion'. Strategic Management Journal, 25, 1179-97.

Moreau, C. P. and Dahl, D. W. (2005). 'Designing the solution: the impact of constraints on consumers' creativity'. Journal of Consumer Research, 32, 13-22.

Mosakowski, E. (2002). 'Overcoming resource disadvantages in entrepreneurial firms: when less is more'. In Hitt, M., Ireland, D., Sexton, D. and Camp, M. (Eds), Strategic entrepreneurship: Creating an Integrated Mindset. Oxford, England: Blackwell, 106-26.

Mousa, F. T., Marlin, D. and Ritchie, W. J. (2013). 'Configurations of slack and their performance implications: an examination of high-tech IPOs’. Management Decision, 51, 225-47.

Mousa, F. T. and Reed, R. (2013). 'The impact of slack resources on high-tech IPOs'. Entrepreneurship Theory and Practice, 37, 1123-47.

Natividad, G. (2013). 'Financial slack, strategy, and competition in movie distribution'. Organization Science, 24, 846-64.

Ndofor H. A., Sirmon, D. G. and He, X. (2011). 'Firm resources, competitive actions and performance: investigating a mediated model with evidence from the in-vitro diagnostics industry'. Strategic Management Journal, 32, 640-57.

Nohria, N. and Gulati, R. (1997). 'What is the optimum amount of organizational slack?'. European Management Journal, 15, 602-11.

Nohria, N. and Gulati, R. (1996). 'Is slack good or bad for innovation?'. Academy of Management Journal, 39, 1245-64.

Patzelt, H. and Shepherd, D. A. (2009). 'Strategic entrepreneurship at Universities: academic entrepreneurs' assessment of policy programs'. Entrepreneurship Theory and Practice, 33, 319-40.

Penrose, E. T. (1959). The Theory of the Growth of the Firm. Oxford University Press: New York.

Peteraf, M. A. and Barney, J. B. (2003). 'Unraveling the resource-based tangle'. Managerial and Decision Economics, 24, 309-23.

Porac, J. F., Thomas, H. and Baden-Fuller, C. (1989). 'Competitive groups as cognitive communities: the case of Scottish knitwear manufacturers'. Journal of Management Studies, 26, 397-416.

Priem, R. L. and Butler, J. E. (2001). 'Is the resource-based "view" a useful perspective for strategic management research?'. Academy of Management Review, 26, 22-40.

Radjou, N., Prabhu, J. and Ahuja, S. (2012). Jugaad Innovation: Think Frugal, Be Flexible, Generate Breakthrough Growth. New York: Jossey-Bass.

Sapienza, H. J., Korsgaard, M. A. and Forbes, D. P. (2003). 'The self-determination motive and entrepreneurs' choice of financing'. In Katz, J. and Shepherd, D. (Eds), Cognitive Approaches to Entrepreneurship Research. Advances in Entrepreneurship, Firm Emergence, and Growth. Oxford, England: Elsevier/JAI Press, 6, 107-40. 
Selznick, P. (1957). Leadership in Administration. New York: Harper and Row.

Shane, S. and Stuart, T. (2002). 'Organizational endowments and the performance of University startups'. Management Science, 48, 154-70.

Sharfman, M. P., Wolf, G., Chase, R. B. and Tansik, D. A. (1988). 'Antecedents of organizational slack'. Academy of Management Review, 13, 601-14.

Singh, J. V. (1986). 'Performance, slack, and risk taking in organizational decision making'. Academy of Management Journal, 29, 562-85.

Sirmon, D. G., Hitt, M. A., Arregle, J. L and Campbell, J. T. (2010). 'The dynamic interplay of capability strengths and weaknesses: investigating the bases of temporary competitive advantage'. Strategic Management Journal, 31, 1386-409.

Sirmon, D. G., Hitt, M. A., Ireland, R. D. and Gilbert, B. A. (2011). 'Resource orchestration to create competitive advantage: breadth, depth, and life cycle effects'. Journal of Management, 37, 1390-412.

Stevenson, H. H. and Gumpert, D. E. (1985). 'The heart of entrepreneurship'. Harvard Business Review, 63, 85-94.

Starr, J. A. and Macmillan, I. C. (1990). 'Resource cooptation via social contracting: resource acquisition strategies for new ventures'. Strategic Management Journal, 11, 79-92.

Steensma, H. K. and Corley, K. G. (2001). 'Organizational context as a moderator of theories on firm boundaries for technology sourcing'. Academy of Management Journal, 44, 271-91.

Tan, J. and Peng, M. W. (2003). 'Organizational slack and firm performance during economic transitions: two studies from an emerging economy'. Strategic Management Journal, 24, 1249-63.

Thompson, J. D. (1967). Organizations in Action. New York: McGraw-Hill.

Vanacker, T., Collewaert, V. and Paeleman, I. (2013). 'The relationship between slack resources and the performance of entrepreneurial firms: the role of venture capital and angel investors'. Journal of Management Studies, 50, 1070-96.

Verbeke, A. and Yuan, W. (2013). 'The drivers of multinational enterprise subsidiary entrepreneurship in China: a new resource-based view perspective'. Journal of Management Studies, 50, 236-58.

Villalonga, B. (2004). 'Intangible resources, Tobin's q, and sustainability of performance differences’. Journal of Economic Behaviour \& Organization, 54, 205-30.

Voss, G., Sirdeshmukh, D. and Voss, Z. (2008). 'The effects of slack resources and environmental threat on product exploration and exploitation'. Academy of Management Journal, 51, 147-64.

Wang, H., Choi, J., Wan, G. and Dong, J. Q. (2013). 'Slack resources and the rent-generating potential of firm-specific knowledge'. Journal of Management, doi: 10.1177/0149206313484519.

Wernerfelt, B. (1984). 'A Resource-based view of the firm'. Strategic Management Journal, 5, 17180. 
Wiggins, R. R. and Ruefli, T. W. (2005). 'Sustained competitive advantage: temporal dynamics and the incidence and persistence of superior economic performance'. Organization Science, 13, 82-105.

Winborg, J. and Landström, H. (2001). 'Financial bootstrapping in small businesses: examining small business managers' resource acquisition behaviors'. Journal of Business Venturing, 16, 235-54.

Wirtz, B. W., Mathieu, A. and Schilke, O. (2007). 'Strategy in high-velocity environments'. Long Range Planning, 40, 295-313.

Wren, C. and Storey, D. J. (2002). 'Evaluating the effect of soft business support upon small firm performance'. Oxford Economic Papers, 54, 334-65.

Zahra, S. A. (1996). 'Technology strategy and performance: a study of corporate-sponsored and independent biotechnology ventures'. Journal of Business Venturing, 11, 289-321.

Zahra, S. A., Neubaum, D. O. and El-Hagrassey G. M. (2002). 'Competitive analysis and new venture performance: understanding the impact of strategic uncertainty and venture origin'. Entrepreneurship Theory and Practice, 27, 1-28. 
Figure 1: Different Bundles of Slack Resources

FINANCIAL SLACK

\begin{tabular}{c|c|c|}
\multicolumn{4}{c}{ High } & \multicolumn{2}{c|}{ Low } \\
\cline { 2 - 3 } & High & $\begin{array}{c}\text { Selective resource } \\
\text { Parallel resource } \\
\text { abundance (Quadrant I) } \\
\text { constraints in financial } \\
\text { resources (Quadrant III) }\end{array}$ \\
\cline { 2 - 3 } & $\begin{array}{c}\text { Selective resource } \\
\text { constraints in human } \\
\text { resources (Quadrant II) }\end{array}$ & $\begin{array}{c}\text { Parallel resource } \\
\text { constraints (Quadrant IV) }\end{array}$ \\
\hline
\end{tabular}


Figure 2: Surface Plot of the Combined Effects of Financial and HR Slack on Firm Performance

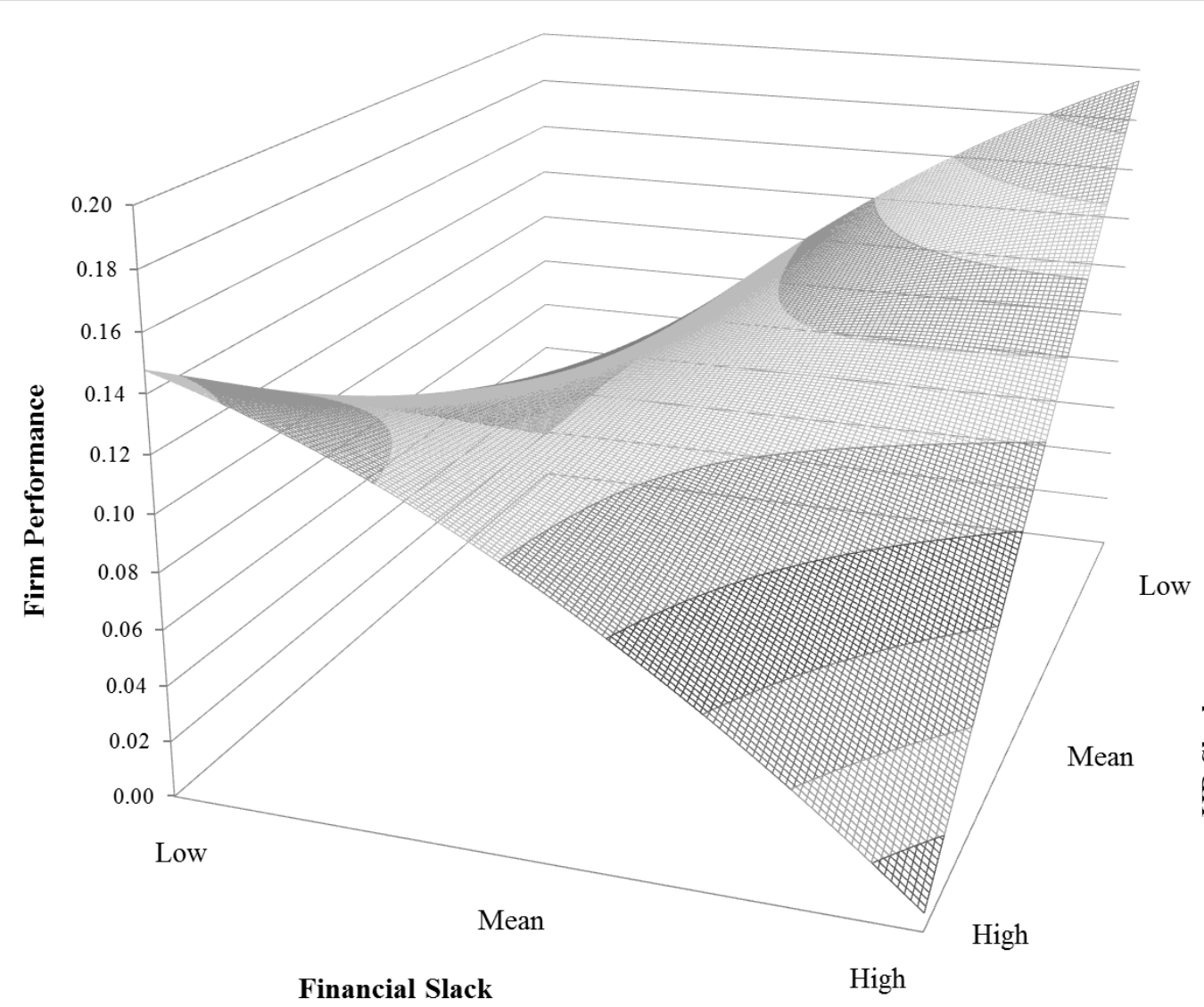

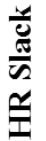

Note. The surface plot uses three standard deviations from the means of financial slack and HR slack. 
Figure 3: Surface Plot of the Combined Effects of Financial and HR Slack on Firm Exit

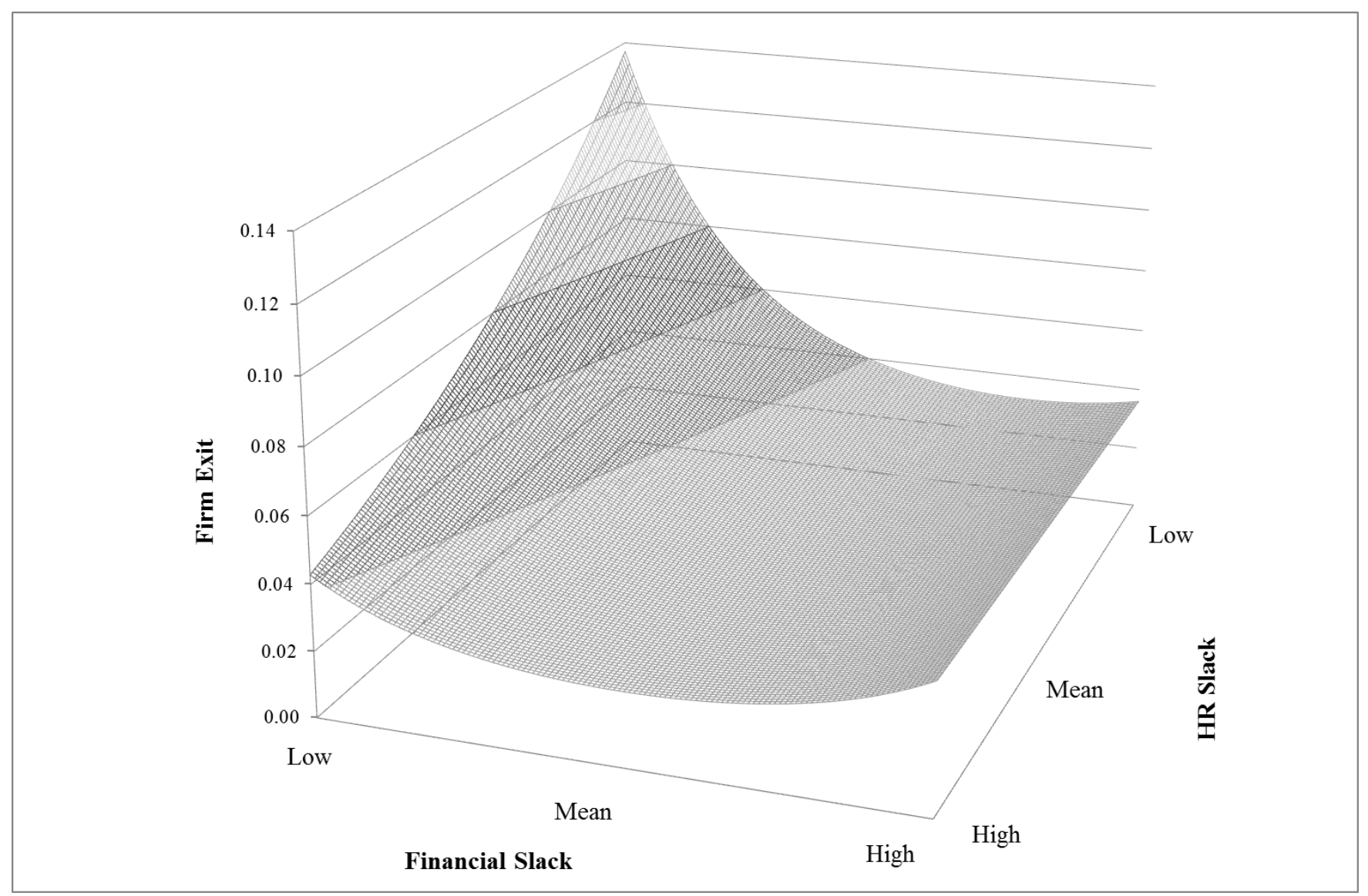

Note. The surface plot uses three standard deviations from the means of financial slack and HR slack. 


\section{Table I: Descriptive Statistics and Correlations}

\begin{tabular}{|c|c|c|c|c|c|c|c|c|c|c|c|c|c|c|c|c|c|c|c|c|}
\hline & Variable $^{a}$ & Mean & $S D$ & Min & $\operatorname{Max}$ & 1 & 2 & 3 & 4 & 5 & 6 & 7 & 8 & 9 & 10 & 11 & 12 & 13 & 14 & 15 \\
\hline 1 & Firm size $^{b}$ & 6.787 & 1.942 & 0.008 & 15.104 & 1.000 & & & & & & & & & & & & & & \\
\hline 2 & Firm age & 8.976 & 5.337 & 1.000 & 25.000 & 0.267 & 1.000 & & & & & & & & & & & & & \\
\hline 3 & Intangible assets ratio & 0.087 & 0.155 & 0.000 & 1.000 & 0.030 & -0.103 & 1.000 & & & & & & & & & & & & \\
\hline 4 & Knowledge intensity ${ }^{\mathrm{b}}$ & 0.067 & 0.314 & 0.000 & 5.420 & 0.137 & 0.003 & 0.039 & 1.000 & & & & & & & & & & & \\
\hline 5 & VC dummy & 0.073 & 0.261 & 0.000 & 1.000 & 0.073 & -0.070 & 0.103 & 0.198 & 1.000 & & & & & & & & & & \\
\hline 6 & Potential slack & -0.008 & 0.300 & -0.838 & 0.511 & 0.030 & 0.075 & -0.024 & 0.028 & 0.005 & 1.000 & & & & & & & & & \\
\hline 7 & Recoverable slack & 0.028 & 0.073 & -0.080 & 0.246 & 0.025 & 0.034 & 0.043 & 0.096 & 0.029 & -0.032 & 1.000 & & & & & & & & \\
\hline 8 & Lagged performance & 0.105 & 0.272 & -0.636 & 0.633 & -0.002 & 0.092 & -0.139 & -0.158 & -0.207 & 0.222 & -0.139 & 1.000 & & & & & & & \\
\hline 9 & $\begin{array}{l}\text { Parallel resource abundance } \\
\text { (Quadrant I) }\end{array}$ & 0.239 & 0.426 & 0.000 & 1.000 & -0.060 & -0.008 & -0.080 & 0.086 & 0.085 & 0.142 & -0.057 & -0.145 & 1.000 & & & & & & \\
\hline 10 & $\begin{array}{l}\text { Selective resource constraints in } \\
\text { human resources (Quandrant II) }\end{array}$ & 0.250 & 0.433 & 0.000 & 1.000 & -0.086 & -0.016 & -0.166 & -0.067 & -0.078 & 0.144 & -0.114 & 0.253 & -0.324 & 1.000 & & & & & \\
\hline 11 & $\begin{array}{l}\text { Selective resource constraints in } \\
\text { financial resources (Quadrant III) }\end{array}$ & 0.258 & 0.437 & 0.000 & 1.000 & 0.050 & 0.011 & 0.221 & 0.007 & 0.044 & -0.163 & 0.079 & -0.189 & -0.330 & -0.341 & 1.000 & & & & \\
\hline 12 & $\begin{array}{l}\text { Parallel resource constraints } \\
\text { (Quadrant IV) }\end{array}$ & 0.241 & 0.428 & 0.000 & 1.000 & 0.093 & 0.016 & 0.023 & -0.025 & -0.055 & -0.120 & 0.089 & 0.079 & -0.315 & -0.326 & -0.332 & 1.000 & & & \\
\hline 13 & Financial slack & 0.057 & 0.202 & -0.232 & 0.556 & -0.187 & -0.025 & -0.238 & 0.019 & 0.013 & 0.302 & -0.149 & 0.112 & 0.419 & 0.466 & -0.443 & -0.431 & 1.000 & & \\
\hline 14 & HR slack & 0.050 & 0.271 & -0.326 & 0.859 & -0.124 & -0.100 & 0.182 & 0.163 & 0.198 & -0.042 & 0.042 & -0.507 & 0.435 & -0.425 & 0.399 & -0.409 & 0.022 & 1.000 & \\
\hline 15 & Performance & 0.099 & 0.266 & -0.636 & 0.633 & -0.034 & 0.072 & -0.102 & -0.154 & -0.189 & 0.058 & -0.121 & 0.639 & -0.132 & 0.183 & -0.107 & 0.053 & 0.051 & -0.385 & 1.000 \\
\hline 16 & Exit & 0.048 & 0.215 & 0.000 & 1.000 & -0.031 & 0.010 & 0.029 & -0.002 & 0.019 & -0.062 & 0.005 & -0.066 & -0.006 & -0.024 & 0.016 & 0.015 & -0.019 & 0.034 & -0.087 \\
\hline
\end{tabular}

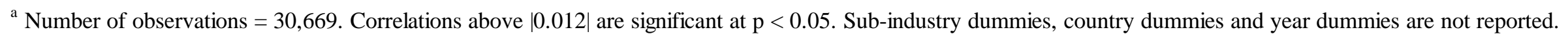

${ }^{\mathrm{b}}$ Log-transformed variable

Variables 5, 9, 10, 11, 12 and 16 are binary thus their correlations should be interpreted with care.
} 
Table II: Descriptive Statistics of the Different Bundles of Slack Resources

FINANCIAL SLACK

\begin{tabular}{|c|c|c|c|c|c|c|}
\hline \multirow{8}{*}{ High } & \multicolumn{3}{|c|}{ High } & \multicolumn{3}{|c|}{ Low } \\
\hline & \multicolumn{3}{|c|}{$\begin{array}{l}\text { Parallel resource abundance } \\
\qquad(\text { Quadrant I })^{\mathbf{a}}\end{array}$} & \multicolumn{3}{|c|}{$\begin{array}{l}\text { Selective resource constraints in } \\
\text { financial resources (Quadrant III) }\end{array}$} \\
\hline & & Mean & $S D$ & & Mean & $S D$ \\
\hline & Financial slack & 0.208 & 0.170 & Financial slack & -0.096 & 0.070 \\
\hline & HR slack & 0.261 & 0.262 & HR slack & 0.234 & 0.231 \\
\hline & Performance & 0.036 & 0.311 & Performance & 0.050 & 0.258 \\
\hline & Exit & 0.046 & 0.210 & Exit & 0.054 & 0.226 \\
\hline & \multicolumn{3}{|c|}{$\begin{array}{l}\text { Selective resource constraints in } \\
\text { human resources (Quadrant II) }\end{array}$} & \multicolumn{3}{|c|}{$\begin{array}{l}\text { Parallel resource constraints } \\
{\text { (Quadrant } \mathbf{I V})^{\mathrm{d}}}\end{array}$} \\
\hline \multirow{5}{*}{ Low } & & Mean & $S D$ & & Mean & $S D$ \\
\hline & Financial slack & 0.220 & 0.173 & Financial slack & -0.098 & 0.070 \\
\hline & HR slack & -0.149 & 0.097 & HR slack & -0.146 & 0.098 \\
\hline & Performance & 0.183 & 0.247 & Performance & 0.124 & 0.216 \\
\hline & Exit & 0.039 & 0.195 & Exit & 0.054 & 0.226 \\
\hline
\end{tabular}

${ }^{\mathrm{a}}$ Number of observations $=7,315$

${ }^{\mathrm{b}}$ Number of observations $=7,681$

${ }^{\mathrm{c}}$ Number of observations $=7,904$

${ }^{\mathrm{d}}$ Number of observations $=7,393$

Note. Although in any given year, firm exit rates are relatively low (i.e., between 5.4\% and 3.9\%), 34.10\% of firms eventually exit the sample during the entire study period. 
Table III: GEE Regression Results for Firm Performance

\begin{tabular}{|c|c|c|c|c|c|c|c|c|c|c|c|c|c|c|}
\hline \multirow[b]{3}{*}{ Intercept } & \multicolumn{5}{|c|}{ All firms } & \multicolumn{4}{|c|}{ New firms } & \multicolumn{5}{|c|}{ Later-stage firms } \\
\hline & \multicolumn{3}{|c|}{ Model 1} & \multicolumn{2}{|c|}{ Model 2} & \multicolumn{2}{|c|}{ Model 3} & \multicolumn{2}{|c|}{ Model 4} & \multicolumn{3}{|c|}{ Model 5} & \multicolumn{2}{|c|}{ Model 6} \\
\hline & 0.079 & $* * *$ & $(0.008)$ & $0.144 * * *$ & $(0.008)$ & $0.064 * * *$ & $(0.011)$ & $0.143 * * *$ & $(0.012)$ & 0.096 & $* * *$ & $(0.012)$ & $0.123 * * *$ & $(0.012)$ \\
\hline Firm size & -0.005 & $* * *$ & $(0.001)$ & $-0.009 * * *$ & $(0.001)$ & $-0.006 * * *$ & $(0.001)$ & $-0.011 * * *$ & $(0.001)$ & -0.005 & $* * *$ & $(0.001)$ & $-0.006 * * *$ & $(0.001)$ \\
\hline Firm age & 0.002 & $* * *$ & $(0.000)$ & $0.002 * * *$ & $(0.000)$ & $0.004 * * *$ & $(0.001)$ & $0.004 * * *$ & $(0.001)$ & 0.001 & $* *$ & $(0.000)$ & $0.001 * *$ & $(0.000)$ \\
\hline Intangible assets ratio & -0.005 & & $(0.009)$ & 0.006 & $(0.009)$ & -0.009 & $(0.012)$ & 0.000 & $(0.012)$ & 0.012 & & $(0.012)$ & 0.020 & $(0.012)$ \\
\hline Knowledge intensity & -0.028 & $* * *$ & $(0.005)$ & $-0.017 * * *$ & $(0.005)$ & $-0.037 * * *$ & $(0.007)$ & $-0.022 * * *$ & $(0.007)$ & -0.020 & $* * *$ & $(0.006)$ & $-0.015 * *$ & $(0.006)$ \\
\hline VC dummy & -0.054 & $* * *$ & $(0.006)$ & $-0.043 * * *$ & $(0.006)$ & $-0.059 * * *$ & $(0.007)$ & $-0.045 * * *$ & $(0.007)$ & -0.035 & $* * *$ & $(0.008)$ & $-0.030 * * *$ & $(0.008)$ \\
\hline Potential slack & -0.102 & $* * *$ & $(0.005)$ & $-0.091 * * *$ & $(0.005)$ & $-0.109 * * *$ & $(0.007)$ & $-0.093 * * *$ & $(0.007)$ & -0.065 & $* * *$ & $(0.007)$ & $-0.064 * * *$ & $(0.007)$ \\
\hline Potential slack squared & -0.052 & $* * *$ & $(0.010)$ & $-0.041 * * *$ & $(0.010)$ & $-0.061 * * *$ & $(0.014)$ & $-0.043 * * *$ & $(0.014)$ & -0.036 & $* * *$ & $(0.013)$ & $-0.034 * *$ & $(0.013)$ \\
\hline Recoverable slack & 0.037 & & $(0.040)$ & -0.008 & $(0.040)$ & 0.093 & $(0.061)$ & 0.037 & $(0.060)$ & 0.007 & & $(0.047)$ & -0.014 & $(0.048)$ \\
\hline Recoverable slack squared & -1.014 & $* * *$ & $(0.199)$ & $-0.723 * * *$ & $(0.198)$ & $-1.281 * * *$ & $(0.302)$ & $-0.924 * * *$ & $(0.299)$ & -0.770 & $* * *$ & $(0.239)$ & $-0.620 * *$ & $(0.240)$ \\
\hline Lagged performance & 0.522 & $* * *$ & $(0.005)$ & $0.476 * * *$ & $(0.006)$ & $0.560 * * *$ & $(0.007)$ & $0.509 * * *$ & $(0.008)$ & 0.521 & $* * *$ & $(0.008)$ & $0.496 * * *$ & $(0.008)$ \\
\hline $\begin{array}{l}\text { Selective resource constraints in } \\
\text { human resources (Quandrant II) }\end{array}$ & 0.025 & $* * *$ & $(0.004)$ & & & $0.032 * * *$ & $(0.005)$ & & & 0.016 & $* * *$ & $(0.005)$ & & \\
\hline $\begin{array}{l}\text { Parallel resource constraints } \\
\text { (Quadrant IV) }\end{array}$ & 0.011 & $* * *$ & $(0.004)$ & & & $0.014 * * *$ & $(0.005)$ & & & 0.002 & & $(0.005)$ & & \\
\hline Financial slack & & & & $0.028 * * *$ & $(0.011)$ & & & $0.043 * * *$ & $(0.016)$ & & & & 0.021 & $(0.014)$ \\
\hline Financial slack squared & & & & $-0.049 *$ & $(0.028)$ & & & $-0.094 * *$ & $(0.041)$ & & & & 0.011 & $(0.037)$ \\
\hline HR slack ${ }^{a}$ & & & & -0.897 & $(0.776)$ & & & -0.332 & $(1.066)$ & & & & -1.375 & $(1.017)$ \\
\hline HR slack squared ${ }^{a}$ & & & & $-0.160 * * *$ & $(0.013)$ & & & $-0.174 * * *$ & $(0.017)$ & & & & $-0.100 * * *$ & $(0.020)$ \\
\hline Financial slack x HR slack ${ }^{a}$ & & & & $-15.991 * * *$ & $(1.932)$ & & & $-18.554 * * *$ & $(2.522)$ & & & & $-9.488 * * *$ & $(3.055)$ \\
\hline N (Firm-years) & & 0,669 & & 30,66 & & 16,249 & & 16,249 & & & 4,420 & & 14,420 & \\
\hline Number of firms & & 4,715 & & 4,715 & & 3,802 & & 3,802 & & & 2,828 & & 2,828 & \\
\hline Wald chi-square & 15,17 & 3.630 & $0 * * *$ & $15,814.55$ & $0 * * *$ & $10,814.920$ & $0 * * *$ & $11,428.47$ & $0 * * *$ & 6,39 & 4.680 & $0 * * *$ & $6,443.720$ & $* * *$ \\
\hline
\end{tabular}

${ }^{\mathrm{a}} \mathrm{HR}$ slack/100

Note. Conservative two-tailed tests, where $* \mathrm{p}<0.10, * * \mathrm{p}<0.05, * * * \mathrm{p}<0.01$. Sub-industry, country and year controls are included but not reported. Unstandardized regression coefficients are shown. Standard errors are in parentheses. 
Table IV: GEE Regression Results for Firm Exit

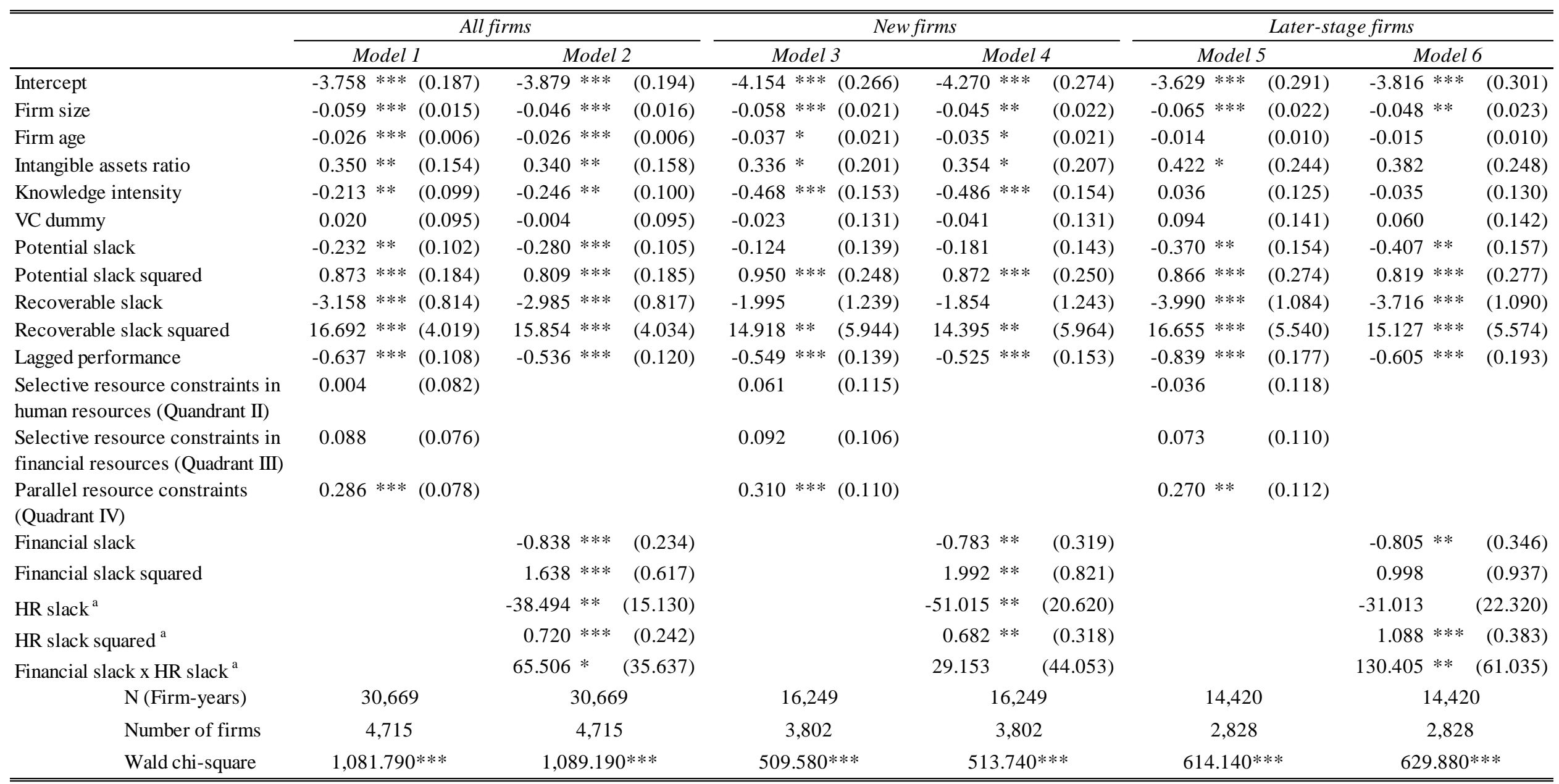

\section{${ }^{\mathrm{a}}$ HR slack/100}

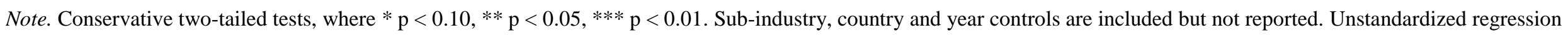
coefficients are shown. Standard errors are in parentheses. 


\section{Appendix A: Sample Description}

\begin{tabular}{lrrrr}
\hline \hline & Number of firms & $\%$ & Number of firm-year \\
observations
\end{tabular}




\section{Appendix B: Robustness Tests}

We fitted multiple additional models to test the robustness of our findings and assess the strength of alternative explanations. These models are not reported because of space considerations, but they are available from the authors upon request.

First, we use alternative dependent variables. For firm performance, we use EBITDA (in millions of euro) not scaled by total assets. For firm survival, we construct an alternative measure in which we do not consider mergers and acquisitions as exits. Mergers and acquisitions not only involve unsuccessful firms (i.e., fire sales) but may also involve very successful firms. The results remain qualitatively similar with these alternative dependent variables.

Second, we conduct additional tests to control for the possibility that slack resources may be endogenously determined. Following Wang et al. (2013), we apply the predicted value approach, which helps to separate out the endogenously determined variance in the levels of financial and HR slack. Specifically, we first estimate models with cash on total assets (employment cost on sales) as the dependent variable. These models include past performance (this measure is clearly exogenous to current slack levels because current slack levels do not determine past performance), basic firm characteristics, sub-industry dummies and year dummies. The difference between the actual and predicted level of resources (from the first models) represents resource slack and is subsequently used in the second-stage performance and survival regressions to reduce any biases caused by endogeneity. The results remain similar.

Third, we test whether our results are stable across different institutional environments. Specifically, we make a distinction between common law countries (the UK) and civil law countries (Belgium, France, Italy and Spain). The size and breadth of financial markets and the flexibility of labor markets are fundamentally different across common law and civil law countries. However, we find qualitatively similar results in both environments. 
Fourth, we test if our findings are limited to ICT firms or have broader implications for other technology-based firms. For this purpose, we use data from VICO on firms in other technology-based industries, such as biotechnology, robotics and nanotechnology, among others. Our results are again qualitatively similar to those reported before.

Finally, instead of splitting the data into new and later-stage firms to test Hypothesis 3, we conduct GEE regressions on the total sample, including the main, squared and interaction terms of financial and HR slack and the two- and three-way interactions with age. This alternative specification leads to virtually identical results. 